\title{
Praca lekarzy i personelu medycznego nad trajektorią rzadkiej choroby dziecka i jego rodziny. Analiza biografii
}

\begin{abstract}
Streszczenie
W artykule przedstawiam temat pracy nad uczuciami podejmowanej przez lekarzy i personel medyczny wobec dziecka z rzadką chorobą i jego najbliższej rodziny. Powołuję się na socjologiczną koncepcję trajektorii choroby. Zastosowałam metodę wywiadu narracyjnego w ujęciu Frütza Schitzego. W ostatniej części artykułu prezentuję wyniki badań przeprowadzonych z matką osoby chorej. Respondentka przedstawia współpracę ze specjalistami w negatywnym świetle. Zarówno lekarze, jak i pielęgniarki nie podejmują się pracy nad interakcjami pacjenta i jego najbliższych, nie stosuje się też pracy nad budowaniem zaufania do nich oraz działań porządkujących biografię pacjenta. Taka praca ma duże znaczenie w leczeniu dziecka oraz w procesie wsparcia jego najbliższych. Działania podejmowane przez specjalistów naznaczają życie chorego i jego rodziny nie tylko w aspekcie dotyczącym zdrowia fizycznego. Dotyczą również dobrostanu rodziny, jej emocjonalnych zasobów. Rezultatem ewidentnych błędów w tych działaniach jest nieprzepracowanie przez matkę dziecka chorego trudnego doświadczenia biograficznego, co może mieć konsekwencje zarówno w życiu narratorki, jak i całej jej rodziny.
\end{abstract}

\section{Słowa kluczowe:}

rzadka choroba, dziecko, rodzina, praca nad trajektorią, praca nad odczuciami, biografia

1 Urszula Klajmon-Lech, Wydział Sztuki i Nauk o Edukacji, Uniwersytet Śląski w Katowicach, Polska, e-mail: urszula.klajmon-lech@us.edu.pl, ORCID ID: https://orcid.org/0000-0003-4195-2094. 


\begin{abstract}
In this article, I present the topic of work on the feelings undertaken by doctors and medical staff towards a child with a rare disease and its immediate family. I refer to the sociological concept of the trajectory of the disease. I used the method of the narrative interview in terms of Frütz Schitze. In the last part of the article, I present the results of research carried out with the mother of the sick person. The respondent presents cooperation with specialists in a negative light. Both doctors and nurses do not undertake interactional work of the patient and his relatives, nor do they trustt work in them and biographical work. Such work is of great importance in the treatment of the child and in the process of supporting his relatives. Actions taken by specialists affect the life of the patient and his family not only in terms of physical health. They are also about the well-being of the family, its emotional resources. The result of evident mistakes in these actions is the fact that the mother of the sick child does not work through a difficult biographical experience.
\end{abstract}

\title{
Keywords:
}

rare disease, child, family, the trajectory work, work on the feelings, biography

\section{WSTĘP}

Informacja o rzadkiej chorobie, czyli jednostce występującej nie częściej niż 5 na 10000 osób, mającej najczęściej podłoże genetyczne (Wakap, Lambert, Orly, Rodwell, Gueydan, 2020; Śmigiel, Łaczmańska, 2012), będącej schorzeniem o charakterze przewlekłym i ciężkim - jest ciosem dla osoby nią dotkniętej, a także dla jej najbliższych. Rozpoczyna się nowy etap w życiu dziecka i jego rodziny - czas naznaczony procesem leczenia, terapii, licznych wizyt w szpitalu, kontaktów ze specjalistami genetykami, neurologami, terapeutami, logopedami itd.

Lekarze i personel medyczny pełnią bardzo istotną rolę nie tylko w procesie leczenia, ale także adaptacji do życia z chorobą. W zaprezentowaniu owej szczególnej funkcji przydatne są dla mnie propozycje Anzelma Straussa (Strauss i in., 1985), który określa je mianem pracy nad trajektorią choroby (trajectory work). Kategorię trajektorii autor tłumaczy w następujący sposób: „ukuliśmy termin trajektorii, aby opowiedzieć nie tylko o rozwoju choroby pacjenta, ale o całkowitej organizacji pracy wykonanej nad przebiegiem choroby, plus jej wpływ na osoby wykonujące tę pracę i jej organizację. Dla różnych chorób trajektoria będzie obejmowała różne medyczne i opiekuńcze działania, różne rodzaje umiejętności 
i inne środki, różny podział zadań wśród pracowników (włączając być może krewnych i samego pacjenta), będzie obejmowała ona jednocześnie całkowicie różne stosunki - instrumentalne i ekspresyjne” (Konecki, 2015, s. 27).

Tak więc lekarze i personel medyczny, pracując nad trajektorią choroby pacjenta, ale także pośrednio - osób mu najbliższych, opiekujących się nim, jego rodziny - wykonują szereg skomplikowanych, profesjonalnych działań, takich jak praca diagnostyczna, czynności służące kontroli stanu pacjenta i przewidywaniu rozwoju przebiegu jego choroby (prześwietlenie rentgenowskie, badanie EKG, zastosowanie odpowiednich leków, mierzenie ciśnienia itp.), podejmowanie decyzji, nieraz bardzo trudnych i ryzykownych, dotyczących leczenia (decyzja o operacji, zastosowaniu alternatywnych form terapii). W sytuacjach szczególnie trudnych i skomplikowanych, takich jak natężenie choroby, odbywają się debaty nad trajektorią (trajectory debates), dotyczące podejmowanych decyzji, w których „daje się słyszeć wiele głosów, niekiedy pojedyncze głosy, ale niektóre głośno i wyraźnie wyrażające pogląd, dlaczego choroba wymknęła się spod kontroli, dlaczego pojawiły się nowe objawy czy nowe choroby, jakie alternatywne linie działania powinny zostać podjęte, kto powinien zaangażować się w te działania, a kto powinien zostać odsunięty itp.” (Strauss i in., 2012). Ważnym elementem pracy nad trajektorią choroby, którą wykonują lekarze wraz z personelem medycznym, oprócz wymienionych działań medycznych i decyzji jest praca nad odczuciami chorego i jego rodziny. Opiszę ją w dalszej części artykułu.

\section{PRACA NAD ODCZUCIAMI - JAKO ISTOTNY ELEMENT OPANOWANIA TRAJEKTORII CHOROBY}

Trajektoria choroby jest powiązana z odczuwaniem przez chorego i jego najbliższych strachu, niepokoju, wątpliwości, złości, smutku. W wypadku choroby przewlekłej takie stany pogłębia czas jej trwania, a także świadomość zależności od niej, jak i od osób, które zajmują się opieką i leczeniem pacjenta. Ponadto pacjent, który staje się „obiektem” różnych, często żmudnych i bolesnych praktyk medycznych, może buntować się przeciwko przedmiotowemu traktowaniu go przez lekarzy i pomoc medyczną - bez zatroszczenia się o stan jego ducha, o jego potrzeby emocjonalne. Dlatego, jak podkreśla Strauss, oprócz standardowych działań medycznych - w opanowaniu trajektorii duże znaczenie ma praca nad odczuciami pacjenta i jego rodziny. Autor wyróżnia kilka jej rodzajów (Strauss, Fagerhaugh i in., 2012; Riemann, Schütze, 1991). 
Pracę nad interakcjami i zasadami moralnymi wykonują lekarze, pielęgniarki oraz inni pracownicy służby medycznej, którzy poza opieką czysto medyczną - poświęcają czas choremu poprzez rozmowę (uważne słuchanie, niewchodzenie nagle mówiącemu w słowo, niepodnoszenie głosu), nieformalne pogawędki, traktowanie go podmiotowo i z szacunkiem. Poza pracą nad interakcjami z pacjentem, a także jego rodziną wykonywana jest także praca polegająca na ukierunkowaniu (orienting) osoby, niezaskakiwaniu jej, a przygotowaniu do prowadzonych zabiegów, działań, wizyt; wyjaśnianiu pacjentowi tego, co się z nim i dla jego zdrowia robi; ustalaniu tempa - czyli taktyki stosowanej zwłaszcza przez pielęgniarki wykonujące bolesne zabiegi typu oczyszczanie rany czy pobieranie krwi u dziecka. Do ważnych reguł zgodnych z pracą nad interakcjami i zasadami moralnymi należy obowiązek, aby nie robić nic z ciałem kogokolwiek bez uzyskania jego zgody (czy zgody jego prawnych opiekunów).

Zasada budowania zaufania jest ważna w powodzeniu pracy z osobą chorą i jego rodziną, gwarantuje też sprawność i skuteczność działania specjalistów. Jak zaznaczają Strauss i Fagerhaugh (2012, s. 807-808), „stworzenie zaufania może być bardzo proste i wiązać się z poczuciem kompetencji, jak również atencją dla fizycznej, interakcyjnej czy osobistej wrażliwości. Jak nam jednak dobrze wiadomo, zdobycie czyjegoś zaufania może być zadaniem bardzo złożonym, wymagającym mnóstwo czasu, wielu rozmów, demonstracji kompetencji, wielu łagodnych gestów i tym podobnych rzeczy”.

Opieka nad osobą przewlekle chorą, zwłaszcza opieka szpitalna, wiąże się z dużą liczbą zabiegów, co naraża ją na utratę równowagi, cierpliwości, a także panowania nad sobą. Wtedy pomocna staje się praca nad zachowaniem spokoju, którą wykonuje w głównej mierze personel medyczny, wspierając, a nawet zabawiając pacjenta, aby mógł on zachować wtedy spokój. Taki rodzaj pracy nad odczuciami jest szczególnie ważny w opiece nad dzieckiem, które szybko może stracić opanowanie i cierpliwość do bolesnych i czasochłonnych czynności medycznych. Wtedy takie działania, jak trzymanie za rękę, gładzenie po czole, kojące słowa współczucia, podtrzymywanie na duchu (także opiekunów dziecka) nabierają dużego znaczenia. Mogą nawet decydować o skuteczności zabiegu. Taki typ pracy jest najczęstszym i powszechnym typem pracy nad odczuciami.

Z kolei praca biograficzna, służąca przede wszystkim osiągnięciu celów medycznych, nabiera cech wsparcia psychologicznego kierowanego w stronę pacjenta (lub/i jego rodziny). Jej podstawowym przykładem jest wywiad diagnostyczny prowadzony z osobą chorą czy jej rodzicami. Lekarz pozyskuje informacje związane nie tylko z objawami choroby, lecz także z jego tak zwaną medyczną i społeczną historią (social history), dowiaduje się o jego trybie życia, a więc 
pozyskuje informacje, które pośrednio związane są z objawami schorzenia. Taki wywiad prowadzony jest według określonych procedur, jest rzeczowy, przepełniony szeregiem pytań, które (zwłaszcza stawiane już po raz kolejny przez kolejnego lekarza specjalistę) mogą nużyć i denerwować pacjenta. Jednak ten rodzaj badania może przerodzić się w bardziej nieformalną rozmowę, w której dochodzi do wymiany doświadczeń pomiędzy chorym (jego przedstawicielami) a lekarzem, który udziela odpowiedzi na nurtujące pytania, sięga do własnych doświadczeń z innymi pacjentami, opowiada fragmenty własnej biografii powiązane z historią medyczną swojego pacjenta. Pracę biograficzną wykonują także pielęgniarki, żeby usprawnić relacje z osobami, którymi się opiekują, i żeby ułatwić trajektorię pracy. „Oczywiście, jeśli pacjent jest okresowo hospitalizowany na ich oddziale, prawdopodobnie będą dowiadywały się coraz więcej na temat cech jego życia, które później mogą spożytkować w przeprowadzeniu pacjenta przez trudne momenty czy dni w chorobie” (Strauss, Fagerhaugh, 2012, s. 810).

Praca biograficzna jest związana i może przekształcać się w pracę nad tożsamością - czyli pracą nad kwestiami tożsamości jednostkowej, czy też jego problemami natury psychologicznej. Taki rodzaj działania, w obliczu choroby przewlekłej, przedłużającego się pobytu w szpitalu, żmudnych czynności zabiegów z tym związanych - wykonują osoby bliskie choremu - rodzice, rodzeństwo, przyjaciele itd. Jednak także personel szpitala może angażować się w nie, choć z zastosowaniem większego dystansu i mniejszym zaangażowaniem emocjonalnym. „Czasami godzinami prowadzone przez pielęgniarki rozmowy z terminalnie chorymi pacjentami, nawet jeśli im samym sprawiają przyjemność, są zorganizowane tak, aby podnieść pacjenta na duchu albo umożliwić mu zbilansowanie życia. (Strauss, Fagerhaugh, 2012, s. 811). Przykładem tej pracy są rozmowy dotyczące przygotowania osób chorych (ich najbliższych) do życia „po szpitalu” - w nowych warunkach zdrowotnych. Oczywiście pracę nad tożsamością, ze względu na jej wymiar psychologiczny, mogą wykonywać w sposób bardziej profesjonalny psychoterapeuci czy psychiatrzy zatrudnieni w szpitalu, a także szpitalni kapelani. Jest to bardzo ważny typ działań, gdyż zaniedbanie ich może powodować nieskuteczność trajektorii pracy i dezintegrację osoby chorej i jej rodziny.

Kiedy lekarze, skupiając się wyłącznie na medycznym aspekcie pracy z pacjentem, zaniedbują wymiar emocjonalny tej pracy, pogarszając kondycję jego zdrowia i samopoczucia, ważna staje się praca naprawcza, którą wykonują pielęgniarki lub inni lekarze. Po bezmyślnym, przedmiotowym potraktowaniu przez specjalistę mogą oni poprzez rozmowę, wymowne spojrzenie, wysłuchanie krytycznych komentarzy pomóc choremu wrócić do wewnętrznej równowagi. 
W swojej koncepcji trajektorii Strauss wymienia jeszcze jeden rodzaj pracy nad odczuciami, jakim jest praca nad kontekstami świadomości, dotycząca głównie pacjenta w stanie bardzo ciężkim, śmiertelnym. Ważne jest wtedy opanowanie personelu, wcześniejsze uzgodnienie wyjaśnień na pytanie pacjenta, by z niespójnych wyjaśnień nie nabrał podejrzeń dotyczących swego stanu zdrowia. Personel dąży do utrzymania tzw. zamkniętego kontekstu świadomości, kiedy jeden z uczestników interakcji nie wie zarówno o tożsamości drugiego uczestnika, jak też o poglądach na tożsamość pierwszego.

Warto zaznaczyć, że opisywana praca nad odczuciami jest i powinna być wykonywana nie tylko przez specjalistów, ale także - a czasem przede wszystkim - przez osoby bliskie i odpowiedzialne za chorego. Kiedy jest nim dziecko, takie działania wykonują rodzice. Trzeba też jednak podkreślić, że oni sami potrzebują emocjonalnego wsparcia, tak więc są wykonawcami z jednej i - odbiorcami z drugiej strony pracy nad odczuciami. Choć ten typ pracy nie zawsze jest oceniany jako istotny w perspektywie leczenia pacjenta, jednak jego znaczenie jest nie do przecenienia. Jak podkreśla autor koncepcji trajektorii, „ryzyko zignorowania osobistej historii pacjenta czy zignorowania pracy biograficznej jest takie, że zadania trajektoryjne zostaną utrudnione albo zaniechane, i że zostanie uruchomiona opadająca spirala prowadząca do wycofania się obu stron lub personelu z interakcji, ze szkodą zarówno dla całego oddziału, jak i trajektorii pracy - nie wspominając o nastrojach pacjentów i opiece medycznej” (Strauss, Fagerhaugh, 2012, s. 812).

\section{UZASADNIENIE STANOWISKA BADAWCZEGO}

W swoich badaniach podjęłam się próby odpowiedzi na problem: Czy/w jaki sposób prowadzona jest praca nad odczuciami wobec dziecka z rzadką chorobą oraz jego matki?

W 2015 i 2019 roku przeprowadziłam wywiady narracyjne z matką 16-letniego dziecka z zespołem Draveta². Wywiady zostały przeprowadzone według metodologii Fritza Schützego. Do najważniejszych założeń opisywanej metody należy przekonanie o procesualnym charakterze rzeczywistości społecznej, refleksja dotycząca ścisłej zależności pomiędzy zachowaniem osoby a jej relacjami

2 Zespół Draveta (Dravet Syndrome, DS.) to rzadka, genetycznie uwarunkowana dysfunkcja mózgu (encefalopatia), przyjmująca formę bardzo ciężkiej i słabo reagującej na jakiekolwiek leczenie padaczki, z opóźnieniem ruchowym i behawioralnym, upośledzeniem umysłowym oraz zakłóceniami autonomicznego układu nerwowego (Chipaux, Dulac, 2008). 
ze środowiskiem oraz przeświadczenie o zmienności rzeczywistości społecznej (Kostera, 1996).

W odróżnieniu od tradycyjnie pojmowanego wywiadu opartego na przygotowanym przez badacza zestawie pytań wywiad narracyjny polega na stymulacji opowiadania o przeżyciach związanych z uczestnictwem osoby badanej w jakimś wydarzeniu lub ciągu wydarzeń. Założeniu temu towarzyszy przekonanie, iż nie wszystkie formy aktywności osoby są przez nią świadomie konstruowane. Niektóre z nich są czynnikami niezależnymi od człowieka. Jeżeli właśnie one dominują w pewnym momencie życia, osoba „doznaje cierpienia” czy też „znosi trudy życia”. Przeciwieństwem tych stanów jest „działanie”, poprzez które Schütze rozumie intencjonalny charakter aktywności. Z kolei „doznawanie” wiąże się z utratą kontroli nad życiem. Najważniejszych rozstrzygnięć biograficznych poszukuje się w wymienionych wymiarach - działania oraz doznawania. Innym ważnym założeniem metody wywiadu narracyjnego jest przekonanie, iż istnieje zasadnicza zgodność pomiędzy narracją o życiu a jego rzeczywistym przebiegiem (Kos, 2013; Prawda, 1989).

Celem przeprowadzonego badania było poznanie trajektorii choroby dziecka z rzadką chorobą genetyczną oraz trajektorii choroby matki - doznawanych przez nią odczuć, sytuacji rodziny i systemu wsparcia dziecka i rodziny. Wstępna analiza uzyskanego materiału badawczego pozwoliła na wyodrębnienie kilku kategorii tematycznych. Jedną z nich była kategoria pracy lekarzy i personelu medycznego nad trajektorią choroby dziecka i jego matki przedstawiona przez samą narratorkę.

Przeprowadzone przeze mnie badanie trwało 1 godzinę i 54 minuty i zostało nagrane na dyktafon. Jego transkrypcja składa się z 1144 wersów. Wywiady był kontynuacją większego projektu badawczego, którego przedmiotem stały się doświadczenia rodziców dzieci z rzadkimi chorobami genetycznymi ujęte w perspektywie trajektorii (Klajmon-Lech, 2018).

\section{PRACA NAD TRAJEKTORIĄ CHOROBY DZIECKA I JEGO MATKI - ANALIZA NARRACJI}

Narracja jest chronologicznie przedstawionym opisem doświadczeń i przeżyć matki, począwszy od pierwszych dostrzeżonych przez nią objawów choroby syna (trzy dni po urodzeniu), aż do teraźniejszej perspektywy codzienności. Historia choroby dziecka to historia wielu miesięcy spędzonych przez nie i matkę w specjalistycznych szpitalach, to relacja z licznych spotkań z lekarzami oraz personelem medycznym, którzy stają się dla nich osobami znaczącymi (Berger, Luckmann, 
1983). Ten okres jest przedstawiany jako traumatyczny czas dla całej rodziny; źle przeprowadzona praca nad odczuciami lekarzy i pielęgniarek - lub całkowity brak takiej pracy - pogłębiają trajektorię cierpienia (Schütze, 1997) narratorki.

Już w pierwszych dniach życia matka dostrzega symptomy choroby: „marmurkową" skórę, dziwne pocenie się dziecka, brak łaknienia oraz nieprzybieranie na wadze. Symptomy te są jednak ignorowane przez lekarza pediatrę. Mimo tego, że matka codziennie przynosi dziecko do poradni pediatrycznej, gdzie jest ono ważone, i zwraca uwagę specjaliście na objawy choroby, lekarz uspokaja ją, wręcz ustosunkowuje się do jej niepokoju o stan dziecka lekceważąco, wprowadza w zażenowanie, odwołując się do jej wykształcenia (pielęgniarskiego), próbując udowodnić niewłaściwą ocenę zdrowia dziecka:

Poszłam do lekarza i mówi, żeby go zważyć. I on dwa tygodnie po szpitalu przybrał tylko dwadzieścia deko. Maluteńko. No i pan doktor, który tu był w przychodni na B., pan K. mówi mi tak: „Mama, tyś jest pielęgniarka, ty się nie przejmuj, bo tyś jest przewrażliwiona i naprawdę nie zwracaj tak na to za bardzo uwagi!”. Ja mówię: „Panie doktorze, ale mu się leje żółta wydzielina z nosa!”. „To sq jeszcze wody płodowe i proszę się tym nie martwić, wszystko jest w porzq̨dku”. Ja mówię: „Ale on ma takq rosę na nosie”. „Ale wszystko jest w porzq̨dku! Nie martw sięweź tylko kup Bebiko albo tam Nana i mu podawaj”.

Lekarz podkreśla swoją pozycję - władzy i kompetencji, konsekwentnie odrzucając wątpliwości matki i ignorując jej obserwacje. Takie same taktyki stosuje kolejny lekarz, którego wybiera zaniepokojona pogarszającym się stanem dziecka matka. Również tłumaczy brak łaknienia nietolerancją mleka i zaleca jedynie jego zmianę. Lekarze w stosunku do dziecka stosują utarte schematy działania. Nie podejmują polemiki z obawami matki, nie próbują także skonfrontować swojej diagnozy z diagnozą innego specjalisty. Sprawują kontrolę nad interakcją z matką dziecka, wprowadzając ją w poczucie niewiedzy i niekompetencji.

Po dwóch tygodniach od urodzenia dziecka zrozpaczona matka niesie po raz kolejny syna do przychodni i po raz kolejny spotyka się z brakiem jakiejkolwiek interwencji lekarza. Ten zapewnia ją jedynie, że w wypadku pogorszenia stanu dziecka nazajutrz zleci badanie morfologiczne. Kobieta wraca do domu. Po rozmowie z mężem decydują się oboje na wizytę w szpitalu. Lekarka dyżurująca jest przerażona stanem dziecka, obwinia matkę za jego zaniedbanie, nie wierzy w jej zapewnia o częstych wizytach u lekarza:

I przyszłam na ten oddział. Pani doktor S. mówi: „Co się dzieje?”. Ja mówię, że wracam od doktora i że nie przybiera na wadze i mówię: „Niepokoi mnie to”. I ona zaraz zrobiła morfologię, zrobiła mu wszystkie badania, wysłała na cito, to przyszło ekspresem i wszędzie było podkreślone na czerwono, wszędzie. I ona mówi tak: 
Kiedy pani była u lekarza z synem?”. Ja mówię: „Dzisiaj do południa, o dziewiq̨tej rano”. Pani doktor: „A co mi pani głupoty opowiada!” - tak do mnie. Ja mówię: „No byłam u lekarza, mam tutaj nawet zapisane, że byłam u lekarza”. Ona mówi: „Ale pani dziecko umiera, pani dziecko umiera! (podniesionym głosem) Pani dziecko ma sepsę, zapalenie płuc, ropomocz (...). Powiedziałam jej jeszcze raz: „Wracam właśnie od lekarza!”. I ona wzięła telefon, zadzwoniła do przychodni, że przyniosłam dziecko praktycznie w stanie agonalnym, że tego lekarz nie zauważył. Zaraz antybiotyk, zaraz nawadnianie. Ja jestem pielęgniarkq. Ja sobie do teraz nie mogę wybaczyć, że tak zaufałam, po prostu zaufałam lekarzowi bezgranicznie i wydawało mi się, że ja - pielęgniarka nie mogę być i nigdy nie będę mq̨drzejsza od lekarza. Dzisiaj wiem, że się myliłam.

Dopiero w szpitalu lekarka zajmuje się dzieckiem, ratując jego życie. Poza tą najważniejszą pracą - medyczną, wykonuje ona także brutalną pracę nad kontekstami świadomości matki - lakonicznie informując o zagrożeniu życia syna. Zwraca uwagę nieumiejętność i niechęć porozumienia z matką, osadzająca się na braku zaufania wobec niej i jej działań. Wydarzenie opowiedziane przez narratorkę naznacza jej życie. Z perspektywy 16 lat nadal obwinia siebie za zbytnie zaufanie wobec lekarza pierwszego kontaktu. Narratorka, oceniając siebie, łączy dwie różne role: siebie jako matki oraz jako pielęgniarki (zawód wyuczony).

W życiu rodziny rozpoczyna się wieloletni okres pobytów w specjalistycznych szpitalach. To czas bardzo trudny - rozłąki narratorki z mężem i starszym synem, czas, w którym całkowicie poświęca się opiece nad chorym dzieckiem. Wyobrażeniowy idealistyczny obraz specjalistycznej kliniki kontrastuje z rzeczywistością, która ukazuje te instytucje oraz ich pracowników w negatywnym świetle (Klajmon-Lech, 2018). Narratorka przedstawia zacofanie cywilizacyjne szpitali, których władze, pozwalając na opiekę pielęgnacyjną nad dzieckiem sprawowaną przez matkę, nie zapewniają jej podstawowych warunków lokalowych i organizacyjnych (w postaci dodatkowego łóżka czy osobnej sali):

Gdy weszliśmy na oddział, jak zobaczyłam, co tam się dzieje, jak to wyglq̨da (...) pomieszczenia - takie klitki - i tak sobie myślę: „No Jezus Maria, gdzie ja się znalazłam? To jest klinika?”. To miało być coś pięknego, coś wspaniałego, mieli wszyscy tutaj chodzić uśmiechnięci, że przyjechałam do kliniki z dzieckiem. Tak mi się zawsze kojarzyła klinika. I widziałam, że mój mąż był tak speszony, tak wystraszony, on mnie tam zostawił. I pojechał. (...) Dostałam się do takiego pokoju, ten pokój miał szerokość łóżeczka i było tam krzesło. Czyli szerokość pokoju była może z dwa metry i to było takie długie jelito, gdzie metr za tym łóżeczkiem było następne łóżeczko i tam, pamiętam, siedziała taka mama na krześle, gdzie nogami dotykała tego łóżeczka. Ja sobie myślę: „No dali mi to chyba na jednq noc?”. 
I myślę sobie: „Jeśli to to ta druga mama wytrzymuje, to czemu ja mam nie dać rady?" Może mnie przeniosq̨?

W takich warunkach - bez możliwości położenia się na własnym łóżku, w małej czteroosobowej sali bez zaplecza łazienkowego, w szpitalu, w którym nie zapewniono możliwości wykupienia posiłków dla opiekunów, narratorka przebywa przez osiem tygodni. Jest to czas traumatyczny dla niej. Warunki, które zapewnia szpital dziecku i jego matce, świadczą o dehumanizacji tego typu instytucji. Pogłębia je zachowanie personelu medycznego:

I przyszła pielęgniarka i zrypała mnie od razu: po co tyle rzeczy tutaj przywożę?, że oni i tak nie majq miejsca, że oni mi tutaj nic nie udostępniq. Czy karmię? Ja mówię, że karmię piersiq. „No to tu ma pani krzesło”. „A ja mam na tym krześle siedzieć?” „A co pani myślała? Pani jest w szpitalu!” (...) I przychodzi pierwsza noc. I pamiętam - nie miałam gdzie się położyć. Piersi miałam już całe obrzmiałe od pokarmu. Przychodziła, to znów wychodziła pielęgniarka: „Proszę mnie przepuścić, tu nie jest dom, tu jest szpital!” (...) Ani jedzenia dla mnie, bo mój mąż myślał, że będę mogła sobie zajść coś kupić. Nie mogłam się nawet iść umyć. Proszę pielęgniarkę, żeby zajęła się na ten czas dzieckiem, a ona: „Ja nie jestem opiekunka! Co tu pani wymaga ode mnie! Proszę poprosić współlokatorkę!”. No to poszłam się umyć. Ten prysznic brałam dosłownie z trzy minuty. Tylko się namydlić, spłukać i wyjść. I przyszłam szybko, bo P. już beczał. I pamiętam pierwszq noc - „Gdzie ja będę spać? Ja - baba - gdzie ja wejdę do takiego łóżeczka?”. Bo moja współlokatorka była mniejsza, to się tam wcisnęła. No nic, rozłożyłam sobie karimatę na ziemi, ale nie mogłam znowu karmić P., bo miałam zamiast tego krzesła karimatę rozłożonq, nie było więcej miejsca. (...) Wzięłam P. do siebie, na ziemię do leżenia, żeby mu dać pierś. I pamiętam, było gdzieś koło wpół do drugiej w nocy - i przychodzi pielęgniarka. I to, nie, żeby weszła cichutko, tylko głośno, światło, otwiera drzwi jak do chlewa i woła: „G., która to G. ?”. Ja odpowiadam: „No ja”. „A gdzie tam pani leży? A gdzie jest mały?” Ja mówię: „No leży obok mnie”. „Na ziemi?” Ja mówię: „A gdzie mam go dać? Ja karmię”. „No dobra, to podejdę do pani”. Przeszła buciorami po karimacie, po śpiworze, podała mu do tego wenflonu antybiotyk. Ja pytam: „A co on ma podawane?” „A czy ja wiem? Chyba antybiotyk. Co lekarze stwierdzili, to podaję.

Pielęgniarka wykorzystuje i nadużywa swoją pozycję, podkreślając asymetryczność relacji z matką pacjenta. Jej zachowanie jest pozbawione empatii. Narratorka, opisując pierwszą noc pobytu w klinice, podkreśla doznane upokorzenie ze strony personelu medycznego i brak jakiegokolwiek wsparcia. Wobec matki pacjenta nie wykonuje się żadnej pracy nad odczuciami, nie docenia się też jej poświęcenia oraz wkładu w proces leczenia i zdrowienia małego dziecka. Jeszcze trudniejsze do 
zaakceptowania są niehumanitarne praktyki medyczne stosowane wobec małego pacjenta (Klajmon-Lech, 2018), które łączą się z brakiem umiejętności zawodowych i kompetencji pielęgniarek pracujących w klinice:

I wzięli P. na przekłucie. No to sobie myślę: „Będzie fachowa obsługa - w końcu to jest klinika! Szybko mi P. przekłujq". Siedziałam pod salq pół godziny, ten się darł, tak strasznie wrzeszczał. Ja nie wiedziałam, co oni tam robiq. Wbijali się mu do głowy, wbijali się do nóg, wbijali do ręki te igły wszystkie, żeby mu ten wenflon założyć. I mówiq̨: „Uważaj, matka, żebyś mu tego nie wyrwała!”. (...) Tam była tylko jedna taka pielęgniarka, która nam współczuła i ona jako jedyna zawsze, gdy brała P. do przekłucia, mówiła: „Ja będę się starała zrobić to szybko”. P. był kłuty zawsze tyle razy i jak z nim wychodzili, był zawsze siny od płaczu. Ja go tam strasznie tuliłam, ja po prostu go chciałam zgnieść z tej miłości, bo nie wiedziałam, jak mu zapewnić tę miłość, żeby on nie musiał tak cierpieć.

Pielęgniarki stają się ważnymi osobami wykonującymi pracę nad trajektorią choroby małego pacjenta i jego matki. Jak zaznaczałam już w części pierwszej artykułu, jednym z ważnych zadań, które mają wypełniać w tym procesie, są prace związane z budowaniem zaufania oraz zachowaniem spokoju. Analizowana narracja nie przedstawia tego typu pracy. Matka pozytywnie ocenia tylko jedną pielęgniarkę, która zapewnia ją o swoich staraniach i wyraźnie współczuje dziecku. Pracy naprawczej, polegającej na łagodzeniu cierpienia, którą mógłby i powinien wykonywać personel medyczny, podejmuje się matka, która po każdym bolesnym zabiegu przytula syna i okazuje mu miłość.

Po dwumiesięcznym pobycie w klinice dziecko wraca do domu. Ze względu na nawracające niezdiagnozowane ataki padaczki zalecone są specjalistyczne leki. Każdy atak epilepsji łączy się z kilkudniowym pobytem w powiatowym szpitalu. Narratorka wspomina, że w pierwszych latach życia jej syn był kilkadziesiąt razy hospitalizowany. Szczegółowo opisuje krytyczny dzień choroby, decyzje i praktyki lekarskie oraz własne przeżycia:

P. dostał znowu ataku padaczki. $W$ domu podałam mu relanium. I przyszłam na oddział. Pani doktor zapytała mnie, co mu podałam. I zaleciła, żeby jeszcze podać 10 miligram relanium. (...) I pani doktor mówi po piętnastu minutach: „ Jeszcze się nie przestaje trzepać?”. Ja mówię: „Nie”. „To proszę mu podać jeszcze dziesięć”. No to pielęgniarka podała. I w pewnym momencie ta pielęgniarka mówi: „Jezus Maria, on nie oddycha!”. I ja stałam nad nim i tak, jakby to nie było moje dziecko. Stałam i trzymałam go i ona zaczęła go wentylować. Pani doktor szybko kazała wezwać OIOM, a mnie wyjść. Więc wyszłam. I co się okazało, że przedawkowała relanium. P. miał w sumie podane dwadzieścia cztery miligramy, czy dwadzieścia sześć. I on się zatrzymał. I już wzywali OIOM z B. W międzyczasie lekarka podała 
mu coś do żyły i cały czas go wentylowała. I ja stałam przy łóżeczku i pomyślałam: „Dobrze, że go wentyluje”. Powiem ci na dzień dzisiejszy - nienawidzę siebie za to. Zrobiłam tyle błędów, których w życiu nie powinnam zrobić. Ale i tak, jako personel medyczny nie byłabym w stanie tego zrobić, bo by mnie nie dopuścili. Ale teraz widzę, jakie były porobione błędy. Teraz - po tylu latach... Przyjechał OIOM z B. i pierwsze pytanie było: „Co jest podane w żyle?”. Odpowiedziały nie pamiętam co i pani z OIOMU-u złapała i wytargała mu to. Ta krew tak sikała i ona mówi: „Jutro będziemy amputować rękę”. I wychodzq̨c, ona mówi: „Szybko jedziemy na oddział do B. Jutro będzie amputacja ręki, bo był podany lek, który spowodował martwicę w środku". Zaraz pojechałam za nimi do B. i przyjechałam i pamiętam - pani ordynator mówi: „Ale pani dorobiła dziecko!”. Ja pytam: „To co się stało?”. Ona mówi: „Pani syn jest w śpiqczce”. No i okazało się, że przez tyle relanium czternaście dni był w śpiq̨czce. Po pięciu dniach jeżdżenia na OIOM, gdzie go tylko karmiłam, ja mówię do pani ordynator: „Co ja mogę zrobić? Co ja jeszcze mogę zrobić jako mama?”. Oczywiście był żal, ja w domu chodziłam od ściany do ściany, płacz i tylko telefon: „Co z P.? Co z P?”. A ona mi wtedy powiedziała: „Co ja mam pani powiedzieć? Że jest pani wspaniałq matkq? Na to pani czeka?”. Ja mówię: „Nie, ale co ja mogę zrobić?”. I wtedy po takich słowach, wracaliśmy z mężem z $B$, jechaliśmy wtedy dwupasmówkq, pamiętam - naszym starym citroenem, tak strasznie beczałam $w$ tym aucie i $w$ duchu sobie pomyślałam: „Chciałabym, żebyśmy się rozwalili tym autem, żebyśmy się zabili”. Ja nigdy tego nikomu nie mówiłam, bo to takie egoistyczne, ale modliłam się wtedy, żebyśmy mieli wypadek i żebym... (płacze), żebym umarła.

Opisywane doświadczenia z perspektywy kilkunastu lat nadal są żywe i bolesne dla narratorki, na co wskazuje silne nacechowanie emocjonalne wypowiedzi oraz pojawiający się płacz. Nie krytykuje ona błędnych decyzji lekarki ze szpitala powiatowego, których konsekwencją jest stan krytyczny zdrowia dziecka, to ona bierze za nie odpowiedzialność. W komentarzu teoretycznym (Kaźmierska, Waniek, 2020) podkreśla: „Na dzień dzisiejszy - nienawidzę siebie za to. Zrobiłam tyle błędów, których w życiu nie powinnam zrobić”. Ta odpowiedzialność i poczucie winy wynika z godzenia przez narratorkę dwóch ról: jest nie tylko matką dziecka chorego przewlekle, która słucha zaleceń profesjonalistów dotyczących domowej opieki i leczenia dziecka, jest także pielęgniarką, co w jej mniemaniu zobowiązuje ją do większej czujności, pełniejszej odpowiedzialności i podejmowania słusznych decyzji w doborze specjalistów oraz podporządkowywaniu się ich instrukcjom. Stan silnego stresu rodzicielskiego (McCubin, Patterson, 2013) pogłębia w krótkiej rozmowie z mamą lekarka: „Ale pani dorobiła dziecko! (...) Co ja mam pani powiedzieć? Że jest pani wspaniałą matką? Na to pani czeka?”. 
To kolejny przykład brutalnej, okrutnej pracy nad odczuciami matki, którą przeprowadza profesjonalista. Konsekwencją przeżytych doświadczeń, ale także usłyszanych słów jest stan psychiczny matki, u której pojawiają się myśli samobójcze. W wypowiedziach narratorki zacytowanych przeze mnie oraz w innych momentach wywiadu występują komentarze teoretyczne, które ukazują nawracające poczucie winy matki, ciągłe analizowanie bolesnych doświadczeń, co może być rezultatem braku wsparcia ze strony personelu medycznego i lekarzy, a także najbliższych.

W przedstawianiu znaczenia trajektorii choroby przewlekłej (Corbin, Strauss, 1985) zwraca się uwagę na aktywną rolę chorych, ich bliskich, lekarzy i personelu medycznego w kształtowaniu choroby nie tylko poprzez kontrolowanie pojawiających się jej objawów i podejmowanie działań zorientowanych na ratowanie życia, ale także stosowanie „strategii normalizacyjnych”, które mogą być również nazywane pracą nad odczuciami. Strategie te mają umożliwić chorym (ale także ich rodzinom) w miarę satysfakcjonujące funkcjonowanie („normalne” życie), pomimo ograniczeń wynikających z utraty zdrowia. Chodzi więc o podmiotowe sprawstwo osoby chorującej i jej otoczenia społecznego (Skrzypek, 2011), które polega na podejmowaniu działań, mających na celu przezwyciężenie trudności i ograniczeń, a także dążeniu do podtrzymywania „normalności” w codziennym funkcjonowaniu.

W swoim artykule podjęłam się przedstawienia pracy lekarzy i pielęgniarek przede wszystkim pracy nad odczuciami, którą wykonują wobec dziecka z rzadką chorobą oraz jego matki widzianej z perspektywy matki. Personel medyczny bierze aktywny udział w trajektorii choroby osoby doświadczonej cierpieniem oraz jej bliskich. Jednym z ważnych zadań, które powinny wykonywać pielęgniarki, jest praca uspokajająca. Narratorka pozytywnie ocenia działania w tym aspekcie tylko jednej pracownicy szpitala, pozostałe są oschłe wobec pacjenta i jego matki, wręcz traktują ich bezpodmiotowo. Również lekarze są oceniani w tym aspekcie negatywnie. Zarówno lekarze, jak i pielęgniarki nie podejmują się pracy nad interakcjami polegającej na rozmowie z opiekunem pacjenta, uspokajaniu go, wyjaśnianiu zastosowanej terapii, a także pracy z pacjentem - dostosowywaniu tempa bolesnych zabiegów do jego możliwości i nastawień. W praktyce szpitalnej nie stosuje się pracy nad budowaniem zaufania dziecka doświadczającego cierpienia i jego matki.

Istnieje wiele czynników, które mogą składać się na przyczynę wymienionych zaniedbań w pracy nad odczuciami z pacjentem i jego matką. Badacze (Studzińska-Pasieka, 2009, Hojat, 2001) wymieniają wśród nich przepracowanie lekarzy, syndrom wypalenia zawodowego mający swe źródło w niesprawnie funkcjonującym 
systemie opieki zdrowotnej, proces edukacji i socjalizacji lekarskiej nastawiony na tzw. biomedyczną rzeczywistość kliniczną.

Działania podejmowane przez specjalistów naznaczają życie chorego i jego rodziny nie tylko w aspekcie dotyczącym zdrowia fizycznego. Mają wydźwięk o wiele głębszy - dotyczą dobrostanu rodziny, jej emocjonalnych zasobów. Rezultatem ewidentnych błędów w tych działaniach jest nieprzepracowanie przez matkę dziecka chorego trudnego doświadczenia biograficznego, co może mieć konsekwencje zarówno w życiu narratorki, jak i całej jej rodziny.

\section{Bibliografia}

Berger, P., Luckmann T. (1983). Społeczne tworzenie rzeczywistości. Warszawa: PIW.

Chipaux, M., Dulac, O. (2008). Ciężka miokloniczna padaczka niemowląt. Pobrane z: https://www.orpha.net/data/patho/PL/EmergencyGuidelines_ZespolDravetPLPro.pdf.

Corbin, J., Strauss A. (1985). Managing chronic illness at home: three lines of work. Quali-tative Sociology, 8(3), s. 224-247.

Hojat, M. (2001). The Jefferson Scale Of Physical Empathy: Development and Preliminary Psychometric Data. Educational and Psychological Measurement, 6, s. 349-365.

Kaźmierska, K., Waniek, K. (2020). Autobiograficzny wywiad narracyjny. Metoda - technika - analiza. Łódź: Wyd. UŁ.

Klajmon-Lech, U. (2018). Trajektoria życia rodziców dzieci z rzadkimi chorobami genetycznymi. Formy społecznego wsparcia. Toruń: Wyd. Adam Marszałek.

Konecki, T. (2015). Anzelm L. Strauss - pragmatyczne korzenie, pragmatyczne konsekwencje. Przeglq̨d Socjologii Jakościowej, tom XI, 1, s. 13-39.

Kos, E. (2013). Wywiad narracyjny jako metoda badań empirycznych. W: D. Urbaniak-Zając, E. Kos, Badania jakościowe w pedagogice (s. 91-116). Warszawa: PWN.

Kostera, M. (1996). Opowieści o ludziach, zwyczajach i organizacjach, czyli „wykładki”. Warszawa: WSPiZ.

McCubin, H.I., Patterson, J.M. (2013). The Family Stress Process: The Double ABCX Model of Adjustment and Adaptation. W: H.I. McCubin, M.B. Sussman, J.M. Patterson (red.), Social Stress and The Family: Advences and Developments in Family Stresss Therapy and Research (s. 7-37). London-New York: Routledge.

Prawda, M. (1989). Biograficzne odtwarzanie rzeczywistości (o koncepcji badań biograficznych Fritza Schütze). Studia Socjologiczne, 4, s. 84-85.

Riemann, G., Schütze, F. (1991). , ,Trajectory” as a Basic Theoretical Concept for Analyzing Suffering and Disordely Social Processes. W: D.R. Maines (red.), Social Organization and Social Processes. Essays in Honor of Anselm Strauss (s. 333-347). Hawthorne: Aldine de Gruyter.

Schütze, F. (1997). Trajektorie cierpienia jako przedmiot badań socjologii interpretatywnej. Studia Socjologiczne, 1(144), s. 11-56.

Skrzypek, M. (2011). Perspektywa chorego w socjologii choroby przewlekłej. Lublin: Wyd. KUL. 
Strauss, A.L. (2012). Trajektorie choroby. W: K. Kaźmierska (red.), Metoda biograficzna w socjologii (s. 373-388). Kraków: Nomos.

Strauss, A.L. i in. (1985). Social Organization of Medical Work. Chicago-London: Uniwersity of Chicago Presss.

Strauss, A.L., Fagerhaugh, S. i in. (2012). Praca nad odczuciami. W: K. Kaźmierska (red.), Metoda biograficzna w socjologii (s. 780-824). Kraków: Nomos.

Studzińska-Pasieka, K. (2009), Paradygmat profesji w doświadczeniach zawodowych lekarzy i opiniach studentów medycyny. Analiza na przykładzie łódzkiego środowiska medycznego. Łódź: Wyd. Wydział Nauk o Zdrowiu, Uniwersytet Medyczny.

Śmigiel, R., Łaczmańska, I. (2012). Podstawowa wiedza potrzebna do zrozumienia chorób genetycznych. W: T. Kaczan, R. Śmigiel (red.), Wczesna interwencja i wspomaganie rozwoju u dzieci z chorobami genetycznymi (s. 7-39). Kraków: Wyd. Impuls.

Wakap, S.N., Lambert, D.M., Orly i in. (2020). Estimating cumulative point prevalence of rare diseases: analysis of the Orphanet database. European Journal of Human Genetics, 28, s. 165-173. 